\title{
Supposed Periodicity of Redpoll, Carduelis sp., Winter Visitations in Atlantic Canada
}

\author{
ANTHONY J. ERSKINE ${ }^{1}$ and ReID MCMANUS, JR. ${ }^{2}$ \\ ${ }^{1} 16$ Richardson Street, Sackville, New Brunswick E4L 4H6 Canada \\ ${ }^{2} 657$ Royal Road, Memramcook, New Brunswick E4K 1X1 Canada
}

Erskine, Anthony J., and Reid McManus, Jr. 2003. Supposed periodicity of Redpoll, Carduelis sp., visitations in Atlantic Canada. Canadian Field-Naturalist 117(4): 611-620.

Redpoll (primarily Carduelis flammea) data from the New Brunswick-Nova Scotia border region were reviewed in the context of alleged biennial periodicity of irruptions south of their breeding range. Long-term records by the authors suggested a number of departures from visitation in alternate years. Three local Christmas Bird Counts (CBCs) spanning the last 41 winters supported the less-than-regular pattern shown by individual observations. CBC redpoll data from across the Atlantic Provinces revealed annual redpoll visitations across southern New Brunswick, where the largest regional counts (adjusted for observer effort) usually occurred. Visitation to Prince Edward Island, Nova Scotia, and Newfoundland was less frequent, and patterns there were often obscured by scarcity of CBCs with both long-run coverage and redpolls. Examination of those data in relation to varying food availability suggested that irregular abundance but near-annual occurrence of redpoll visitation explains observed observations better than attempts to find periodicity in their irruptions.

Key Words: Common Redpoll, Carduelis flammea, Atlantic Provinces, winter, irruptions, periodicity, food availability.

Redpolls (here discussed as Carduelis flammea; $C$. hornemanni is rare - and under-detected - in our region) breed in the subarctic all around the northern hemisphere. Their occurrence south of the breeding range varies between years and areas, some northernwintering areas holding redpolls in most years, whereas more southern areas have them less frequently.

Several publications discussed "biennial periodicity" in Common Redpoll movements to their winter ranges, but seldom defined unambiguously what they meant by periodicity. The most usual pattern featured southward irruptions mainly or entirely in winters starting in oddnumbered years, but such movements varied greatly in size and distribution - between areas and years. Given biological variation, that was to be expected, but one was left wondering what each author considered as periodicity.

Kennard (1976) used banding totals from 1955-1972, mostly in the northern USA in winter and early spring. Bock and Lepthien (1976) used Christmas Bird Counts (CBCs), in early winter, from 1962-1971, in USA and southern Canada, but included very few (if any) from Atlantic Canada. Troy (1983) examined banding recaptures (none mapped as to or from the Maritimes) for periodicity, distribution, and return to areas used earlier; Brewer et al. (2000) reviewed larger samples of band recoveries - but still none from the Maritimes - for distribution. Houston et al. (2000) cited banding data (1960-2000) and CBC data (1956-2000), in Saskatchewan and Manitoba, but focused on the (at Saskatoon) exceptionally large irruption of 1999-2000. Those data-sets were judged to support "biennial periodicity", to varying degrees.

Hochachka et al. (1999) reviewed earlier studies, noting limited geographic distribution of banding effort and limited seasonal sampling by CBCs. Hochachka et al. (1999) used data from Project FeederWatch, which partly avoided those limitations, but their paper (mainly using FeederWatch data for one winter, 19931994) did not address periodicity directly. They concluded that some redpoll movements occur every year, so these should be viewed as irruptive migration rather than nomadism. They acknowledged that "migration" in redpolls - unlike that of typical migrants - does not often link breeding areas to the same wintering areas each year.

Larson and Bock (1986) examined redpoll CBC data over a longer period (1901-1980), and concluded that "the pattern and synchrony of (redpoll) eruptions... can decay and reform over long periods of time and that such patterns were especially weak between 1921 and $1950 . . . "$. Their graphs also showed some departures from a biennial pattern in earlier and later time periods.

Variations in distance and numbers in redpoll movements generally are assumed to be food-driven. Evidence of this is circumstantial, and we have no new data on it. Southward movements presumably are triggered by food shortage in breeding areas, and continue until food - in the east, especially seeds of birches or alders (Betulaceae) - is found in sufficient quantity to attract transient flocks (Newton 1972), which often are large. Large seed crops of those tree/shrub species, in breeding and northern wintering areas, occur more or less biennially (some references given by Kennard 1976, and Bock and Lepthien 1976), but northern data are scanty where human populations are sparse and economic importance of those trees is slight. Redpolls feed on those seeds (where present), but we know little about relations between levels of seed-crops of those trees and numbers of the birds. Until studies are 
done on this, the role of food-sources in irruptions is only a working hypothesis.

Variations in geography produce many departures from strict latitudinal zonation. Temperature isotherms in summer dip steeply across Canada from northwest to southeast; redpolls breed in the subarctic zone of Alaska and Yukon at latitude 60-70 N (Godfrey 1986), but average $10^{\circ}$ farther south from northern Ontario east to Labrador (Todd 1963; Cadman et al. 1987; Gauthier and Aubry 1996). Redpoll winter range in the prairie provinces follows the north edge of treeless prairies southeast from $54^{\circ} \mathrm{N}$ in Alberta to $50^{\circ}$ in Manitoba (e.g., Smith 1996), fanning out into wooded areas farther southeast (e.g., Cyr et Larivée 1995). East of longitude $65^{\circ} \mathrm{W}$ much area between latitude $47^{\circ}$ and $50^{\circ} \mathrm{N}$ is occupied by the Gulf of St. Lawrence and connecting bays and channels, offering no habitat for redpolls - which in Atlantic Canada must winter farther north or farther south.

Weather patterns also vary geographically. Owing to the convergence, east of $65^{\circ} \mathrm{W}$, of west-east and southwest-northeast storm tracks (Bryson 1966), weather in Atlantic Canada is more unsettled at all seasons than farther west (AJE, personal observation). That probably influences year-to-year variation in habitat suitability for redpolls. Thus, redpoll occurrence patterns likely differ between Atlantic Canada and more western parts of their range in North America.

Our field data on redpolls in southeast New Brunswick and adjacent Nova Scotia, together, spanned longer time-periods than databases used in other studies cited (except Larson and Bock 1986), in a region from which few or no data were available to earlier workers. Our observations were supplemented by data from many CBCs in the Atlantic Provinces, to explore occurrence or absence of patterns over time.

\section{Data sources and methods}

Our field data-sets were based on opportunistic, thus frequently irregular, coverage. McManus (McM) has lived all his life in Memramcook, New Brunswick $\left(46^{\circ} 00^{\prime} \mathrm{N}, 64^{\circ} 33^{\prime} \mathrm{W}\right)$, where he studied birds since 1928. McM noted every bird he saw some winters, but his notes are missing for some other winters; worktime commitments often limited his opportunities for observing and recording data. Before 1940, he seemingly did not recognize redpolls by their calls, so his field notes provided information on incursions mainly in 1940-74. Gaps in his observations or note-keeping sometimes obscured local status of redpolls in the 1940 s and 1950s.

Erskine (AJE) lived in Sackville, New Brunswick (455' N, 64²2'W), in 1960-1968 and 1977-present. His local field activity extended across the Chignecto Isthmus region (area ca. $60 \times 40 \mathrm{~km}$, in MS in prep.). AJE noted redpolls whenever encountered in winter, but he worked elsewhere in parts of some winters. Gaps in AJE records resulting from absences from the area were easily distinguished from times when no redpolls were seen.

Three local CBCs, near Sackville and Cape Tormentine, New Brunswick, and Amherst, Nova Scotia, all with annual coverage 1961-present, provided local comparisons. Selected CBCs elsewhere in New Brunswick, Nova Scotia, Prince Edward Island, Newfoundland - not including Labrador (see Figure 1 and Appendix 1 for CBCs used and locations) - extended the picture geographically. Only CBCs with near-annual coverage for 20 years or more, and with redpolls reported in $10+$ years, were used. Long-run counts that rarely or never reported redpolls were ignored, as were CBCs surveyed in $<20$ years. Most data were taken from regional publications - N.B. Naturalist (earlier Nature News), Nova Scotia Birds (earlier N.S. Bird Society Newsletter), Island Naturalist (Prince Edward Island), and Osprey (Newfoundland); Audubon compilations were much less complete for this region, and duplicated only parts of coverage published locally.

Because effort deployed on CBCs varied greatly (mostly increasing over the study period), all redpoll counts reported were adjusted (roughly) to "counts per 10 party-hours". This made direct comparisons easier between counts with many vs. few observers. The proportions of zero counts (absence, vs. presence, of redpolls) often seemed as informative as maximum (or modal) counts, as a few large counts were reported in years when most $\mathrm{CBC}$ s found no redpolls.

Geographic patterns in Atlantic Canada CBC redpoll data encouraged dividing that data-set, for some comparisons, among seven sub-regions (see Appendix 1 and Figure 1 for $\mathrm{CBCs}$ in each sub-region):

- N-NB: 6 CBC circles in New Brunswick north of latitude $46^{\circ} 40^{\prime} \mathrm{N}$;

- S-NB: 10 circles in New Brunswick south of above, and north of latitude $45^{\circ} 20^{\prime} \mathrm{N}$;

- ScoNB: 5 circles in New Brunswick south of above, and adjoining south (Bay of Fundy) coast;

- Bord: 3 circles in New Brunswick-Nova Scotia border area; these counts were discussed separately as "Local CBCs", but generally showed occurrence patterns similar to those in S-NB;

- N-NS/PE: 6 circles, 3 in Prince Edward Island, 3 in east Nova Scotia (including Cape Breton Island) north of latitude $45^{\circ} 15^{\prime} \mathrm{N}$;

- S-NS: 7 circles in Nova Scotia south and west of above;

- INF: 7 circles in insular Newfoundland.

\section{Results}

Timing of redpoll visitations to New BrunswickNova Scotia border area

In years when redpolls visited our area, first detections ranged from September to December. McM found single redpolls 30 September 1971, 3 October 1947, and 5 October 1948; he noted no other arrivals 


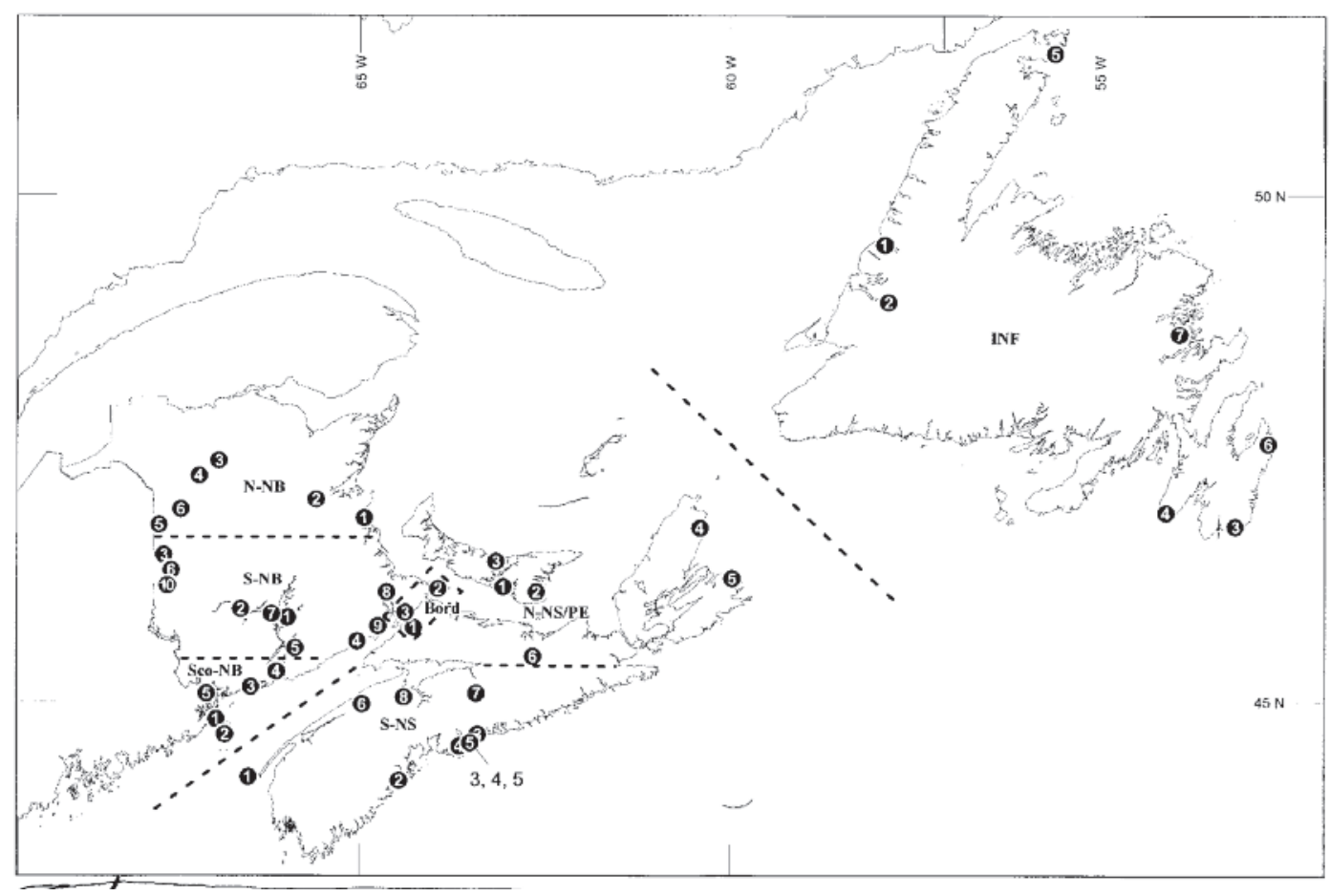

FIGURE 1. Christmas Bird Counts (CBCs) used in redpoll study in Atlantic Provinces, grouped by sub-regions (defined in text, see also Appendix 1). The numbers follow the sequence of entries in Appendix 1.

before mid-October, and AJE's earliest was 31 October 1965. Most arrivals were in November or December. In years when both saw them, McM detected redpoll arrivals earlier than AJE, through regular feeder-watching at home (AJE fed these birds only from 1995). Arrival dates seemed unrelated to size of a winter's redpoll incursion.

Redpolls were in our area, in different winters, for a few days to several months. When many redpolls visited, last sightings usually were in March or April, a few in early May, but large visitations sometimes ended by late February. Departure dates seemed unrelated to numbers or frequency of sightings in the area that year. In winters with few redpolls, records might be scattered through the season, or grouped in a single month; sparse records might reflect observation gaps as much as absence of redpolls.

\section{Comparison of observers and areas}

$\mathrm{McM}$ and AJE both observed, with varying regularity, in nearby areas of New Brunswick in winters of 1960-1961 thru 1967-1968 (plus March 1960 and November-December 1968); after AJE returned to Sackville in September 1977, McM kept few notes of redpolls. Our overlap in coverage here thus spanned eight full winters and parts of five more - of 72 winters when one or both was/were active here.
In the overlap periods, both noted some redpolls in 10 winters, and in two neither saw any. In 1962-1963 AJE saw one flock, and McM none. In the two winters when both found substantial redpoll numbers, AJE was in Sackville only briefly, arriving 18 March 1960, and leaving 10 December 1968; his few local notes in those winters suggested sizable numbers present.

Except for first arrivals, our detection of redpolls seemed generally comparable, and our data were treated as equivalent in other comparisons.

\section{Local observations}

Our data from the New Brunswick-Nova Scotia border region from 1940-1941 to 2001-2002 are summarized in Figure 2 (see also Appendix 2). Those data, based on often variable coverage, sometimes suggested large redpoll "flights" in alternate winters - as reported by observers elsewhere. However, departures from that pattern often were obvious. Sizable redpoll visitations were noted in successive winters [19481949 and 1949-1950; 1968-1969 and 1969-1970; 1986-1987 and 1987-1988], and sometimes two, three, or more winters intervened between sizable irruptions [1943-1944 to $1946-1947$; $1949-1950$ to $1952-$ 1953 ; $1952-1953$ to $1957-1958$ (gaps); $1965-1966$ to 1968-1969; 1973-1974 to 1980-1981 (gaps); 19831984 to $1986-1987$; $1987-1988$ to $1991-1992]$. Some 

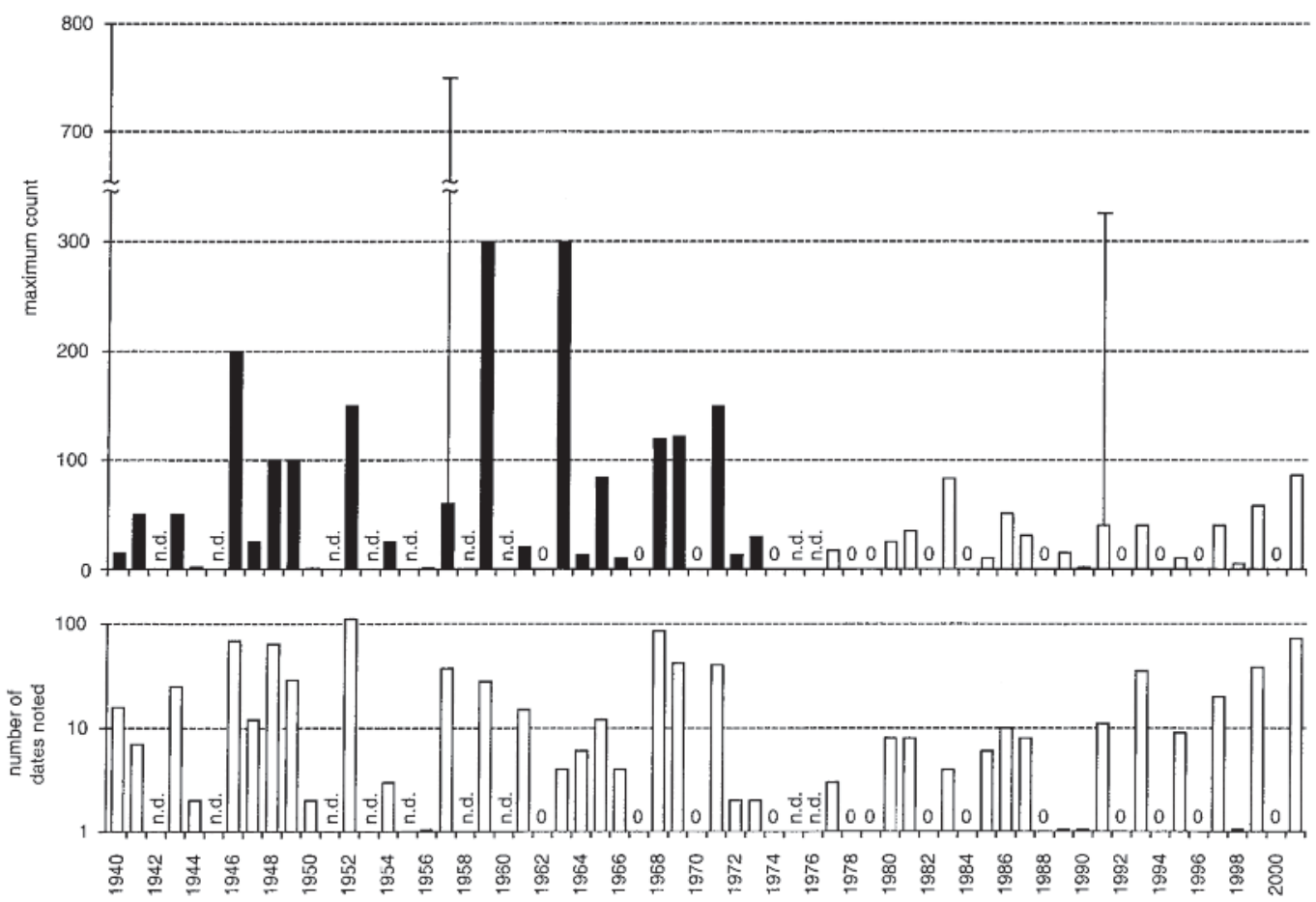

FIGURE 2. Maximum counts of redpolls (upper) and number of dates noted (lower, log scale), for each winter starting in year shown, observed by McManus near Memramcook (black), and by Erskine near Sackville (white), in New Brunswick. Extended lines show outliers, solid or open bar indicating the 2nd highest count in that year.

longer "runs" with few or no redpolls, especially 1952-1958 and 1973-1980, were influenced in part by irregular coverage; others likely were real.

Of those 62 winters, 53 with data, we noted no redpolls at all in only 13 , thus detecting some redpolls in three-quarters of the winters. In 8 of those winters, our sightings totalled $<10$ redpolls each winter. If visitations were strictly "biennial", we might have expected 27 of 53 winters to have very few or no redpolls detected. Some small visitations likely were missed by our varying effort, so comparisons with other regional data may give better perspective on periodicity of redpoll incursions.

\section{Local CBCs}

The three local CBCs included a few observations (by McM and AJE) treated above, but such data comprised very minor proportions of those counts. CBCs involve larger numbers (seen by multiple observers), but their samples are restricted to one day in early winter each year; they may be biased if adverse conditions occurred on count day - or if birds were misidentified. "First arrivals" in December sometimes were on $\mathrm{CBCs}$, in years when observation time was limited earlier in fall.
All three local CBCs were active in 41 winters (1961-2001), but effort on each count increased gradually from 2-5 observers at first to $15-20$ from about 1980, with observer expertise improving as well. Only in 6 (of 41) winters were no redpolls reported on any of those CBCs, and in 6 other years redpolls (1-11/yr) were noted only on one count. Local CBCs usually matched personal observations as to scarcity or absence. As in our observations, these birds were found (in numbers $>10$ ) on CBCs in far more winters than might be expected if "biennial periodicity" was the major or only factor controlling redpoll occurrence.

If redpolls often moved into or through our area before or after the CBC period, season-long observations should have detected those birds in some years when none were met on CBCs, despite the larger observer effort in the latter exercise. Actually, the local $\mathrm{CBCs}$ detected redpolls in an even larger proportion of winters than McM and AJE did. A look at redpoll data from a wider geographic scene seemed desirable.

\section{Other Atlantic Provinces CBCs}

Within the Atlantic Provinces, CBC coverage (minimal before 1960) expanded steadily up to 1980 , in numbers both of counts and of observers. In 1980- 
2000, useful data (defined under "Data sources...") were available annually from $40-45$ regional CBCs, combining reports of about 700 observers. Redpoll data from regional CBCs (1960-2000) showed variable visitation patterns when data were subdivided geographically. Figure 3 shows CBC data from New Brunswick only; see Appendix 3 for other areas and extra details.

One pattern that emerged from study of Figure 3 and Appendix 3 was the near-annual concentration of redpolls in southern N.B. inland from the Bay of Fundy (subregions S-NB and Bord). Redpolls were reported in S-NB, on some or all CBCs, in all 41 winters covered by the $\mathrm{CBC}$ data-set, and the highest single count (adjusted for effort) annually was in $\mathrm{S}-\mathrm{NB}$ in fully half those years. Highest regional counts mostly were at one of six CBCs, all in S-NB or Bord, near latitude $46^{\circ} \mathrm{N}$ - Woodstock, Fredericton, Jemseg, Cambridge-Narrows, Moncton, Cape Tormentine. Concentration of redpolls occurred in southern New Brunswick whether the overall "flight" into (and through?) the Maritimes was large or small.

The (mostly) much smaller samples in $\mathrm{N}-\mathrm{NB}$ showed less consistent patterns, but adjusted counts there in major flight years were generally lower than in S-NB. Counts still farther south (ScoNB, S-NS) also were usually lower than in S-NB. In years with small but widespread redpoll numbers elsewhere, often none were found in those two southern sub-regions.

The more eastern sub-regions (N-NS/PE, INF; Figure 3) were sparsely and often inconsistently sampled by CBCs. Few large (adjusted) counts occurred in INF even in major flight years (Appendix 3). In Prince Edward Island, maximum counts in 1997 and 1999 matched those in S-NB, but in most winters with many redpolls in New Brunswick numbers were much lower in Prince Edward Island; the few longrun counts in eastern Nova Scotia showed no consistent patterns.

A few high counts ("outliers") fell far outside the ranges on other $\mathrm{CBCs}$ in the same years. Such "outliers" may have represented "mass movements" in progress, or just after arrival and before dispersal. The 1991 Cape Tormentine CBC (unadjusted 14159 birds, adjusted 3540) involved flocks moving all day ESEWNW across the circle, thus from northern Nova Scotia into southern New Brunswick. Major incursions to N-NB and S-NB occurred in 1991, but elsewhere in the Maritimes only Glace Bay had an unusually large count (Appendix 3). Other obvious "outliers" at St Anthony (INF; 1976 - 3885 unadjusted) and Kouchibouguac National Park (N-NB; 1990 - 1233 unad-

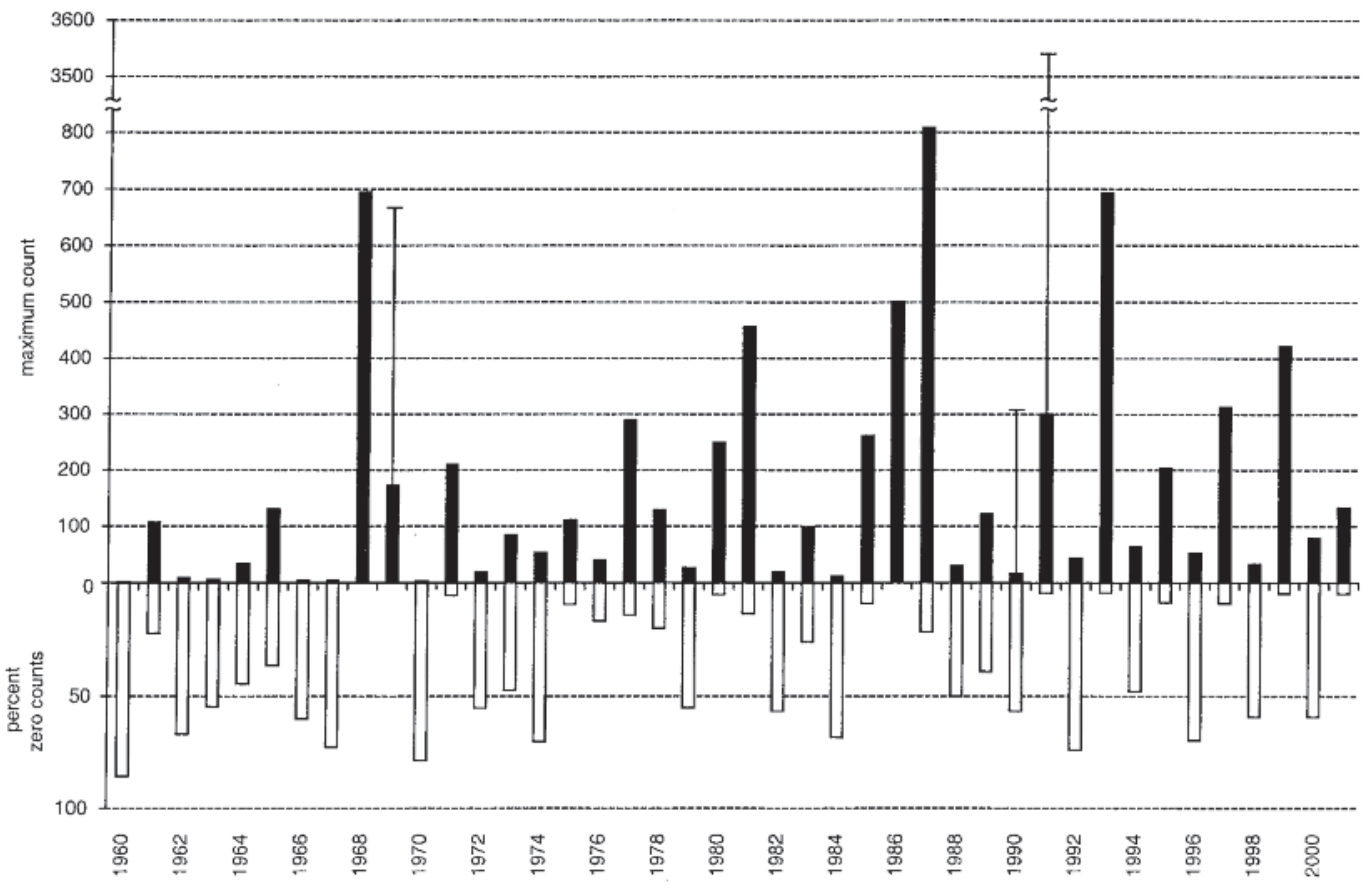

FIGURE 3. Adjusted maximum counts (above $\mathrm{x}$-axis) and percent zero counts (below $\mathrm{x}$-axis, vertical scales differ) of redpolls in New Brunswick CBCs during each winter starting in year shown. Extended lines indicate outliers (as above). 
justed), were in years with minor visitations elsewhere. Outliers at Wolfville (S-NS; 1999 - 4511 unadjusted), St Andrews (ScoNB; 1969 - 800 unadjusted) and Brier Island (S-NS; 1964 - 200 unadjusted) were in areas where high (adjusted) counts always were unusual.

\section{Discussion}

What is left of "biennial periodicity" when many exceptions occur?

Periodicity involving "cycles" with several years between peaks and troughs may not be seriously obscured by irregularities in cycle-length (e.g., Keith 1963), but a short cycle has little space for exceptions. With a biennial rhythm, a "high" year when a "low" is expected produces either three "highs" in a row, or displaces the next "low" to three years after the previous one. Either way, periodicity is lost.

Our own observations (Figure 2) and the New Brunswick CBC data set (Figure 3) showed some periods of alternating winters with (variably) high vs. low or no redpolls, separated by periods when redpoll occurrence did not fit that (or any?) pattern, thus:

$\mathrm{McM} / \mathrm{AJE}$ - high-low alternation in 1959-1960 to 1966-1967, 1969-1970 to $1973-1974,1981-1982$ to 1985-1986, 1989-1990 to 2001-2002;

NB CBCs - high-low alternation in 1969-1970 to $1977-1978,1981-1982$ to $1985-1986,1987-1988$ to 2001-2002. The three later periods of high-low alternation in $\mathrm{CBC}$ redpoll counts thus overlapped with similar periods in the McM/AJE data; the first period of alternation in $\mathrm{McM} / \mathrm{AJE}$ data was not evident in the few CBCs made in S-NB then.

CBC data from Nova Scotia and Prince Edward Island (Appendix 3) also showed high-low alternation of redpoll numbers in 1988-89 to 2001-02, but not in earlier periods. Alternation was never obvious in CBCs from insular Newfoundland, where CBCs and large counts of redpolls were generally scarce.

All methods used here for assessing redpoll "flights" - as large vs. small/absent - are imperfect. Restriction of CBCs to a two-week span of dates makes those data vulnerable to bias, including adverse conditions on count days. With $20+$ counts, scattered through the allowable periods, in most years from 1980, that bias seemed unlikely to be important in New Brunswick then, but it may have blurred earlier comparisons there, and all comparisons using the few (6-7) long-run counts in INF and N-NS/PE sub-regions. CBCs sample only early winter status, whereas redpoll movements often continue erratically through the winter. Despite often irregular coverage, McM/AJE surveys in most winters may have represented redpoll status as well as (or better than) the sparser sampling by CBCs before 1980. Regional data thus suggested that "biennial periodicity" in redpoll occurrence and numbers, if any, was frequently obscured by other factors. Redpoll irruptions to the Maritimes occur every year, as remarked more generally by Hochachka et al.
(1999), but wide variation in numbers, timing, and distribution here indicates that these movements are not normal (annual) migrations.

\section{Numerical variations in winter range arise from factors operating in redpoll breeding areas}

Seed-set in birches, in relation to breeding success of redpolls, has not been studied in northern Canada, but any substantial failure of birch seed-crop in redpoll breeding areas presumably results in an exodus from there before the next winter. For survival of trees there, a missed seed-crop would be "made up" in the next summer, if possible; it would not be delayed another year merely to maintain a pattern of good seed-crops (when few redpolls move southward) only in alternate years. Further, adverse conditions in consecutive summers could result in successive failed seed-crops in a region, leading to major redpoll exodus in successive winters. However, trees "programmed" for a biennial seed-set cycle would not often be able, even under favourable conditions, to produce large seed-crops in successive years (allowing redpolls to remain there through the next winter). Successive years without sizable southward movements of redpolls thus would be less frequent than successive years with such exodus. CBC data suggested successive "lows" in New Brunswick in winters of 1962-1963 and 19631964, and 1966-1967 and 1967-1968, when rather few - and often poorly standardized - CBCs were made there (Appendix 3). Successive lows seemed more frequent in CBCs in Nova Scotia, Prince Edward Island and insular Newfoundland (Appendix 3), probably because not all southward irruptions brought redpolls to those more peripheral areas by December.

Without a seed-set "cycle" inherent in the foodtrees, which may "take over" after interruptions, biennial periodicity of redpoll exodus would be expected to break down for years at a time, as noted by Larson and Bock (1986). Atlantic Canada redpoll data also suggested that such interruptions - and later resumptions - of high-low alternation indeed occurred here several times in the last 70 years. Some of those irregularities occurred during the 1920-1950 period when Larson and Bock (1986) found weak or no evidence of alternating peaks and lows in redpoll numbers on $\mathrm{CBCs}$ in northeastern and north-central states. Irruptions on a "biennial cycle" in a seasonal environment can vary towards shorter length only by becoming annual occurrences. As remarked, some redpolls come to southern New Brunswick every winter, though numbers that come here vary greatly between winters.

\section{Winter distribution of redpolls within the Atlantic Provinces}

Why is southern New Brunswick more attractive to redpolls than other Atlantic Canada wintering areas? Food-tree availability might be greater, but those tree species are very common all across the Atlantic region, 
in early stages of forest succession (Loucks 1962). Most of northern New Brunswick remained under (mostly conifer) forest cover throughout European settlement, but large parts of southern New Brunswick were cleared for agriculture but later abandoned (compare D. S. Erskine 1968). Recent dominance of birches or alders in S-NB forests may be related both to succession (time since field abandonment) and prior use (reduction of seed-sources for other tree species). Compared to S-NB and Bord, most abandonment of agricultural lands in Prince Edward Island occurred after World War 2, and much old-field succession there led directly to spruces (AJE observations). In Nova Scotia, much agricultural land abandonment was underway before 1900 (D.S. Erskine 1968), with very slow forest regrowth. In Newfoundland, agriculture was always minimal. Thus southern New Brunswick may provide larger areas of suitable food trees (birch and alder) for redpolls than other parts of the Atlantic Provinces.

\section{Routes between breeding and wintering areas}

Redpolls arrive in wintering areas from breeding areas somewhere to northward of each observation site, but unambiguous evidence connecting breeding and wintering areas of individuals is lacking. Apparent NW-SE or WNW-ESE movements suggested by indirect banding returns (Troy 1983; Brewer et al. 2000) seem rather to be artifacts of human distribution, with redpolls often using different areas during successive irruptions (Hochachka et al. 1999). Only one indirect recovery - a bird banded at Quebec City March 1956, and recovered in Alaska June 1957 - links a Canadian wintering area with any area in breeding season. Other band returns linking Alaska to areas east of the Great Lakes (Brewer et al. 2000), plus the scarcity of wintering redpolls in the United States west of the Rockies (Bock and Lepthien 1976), suggest that redpolls breeding in Alaska mostly move southeasterly, but that pattern need not be general. Redpolls breeding in Labrador and Ungava evidently do not move southeasterly (= out to sea!). Without contrary evidence, it is plausible to assume that most wintering redpolls originate somewhere in a northward sector with apex at the observation site, with those wintering in the Atlantic Provinces mostly coming from Labrador or Ungava.

Hochachka et al. (1999) thought Project FeederWatch data in their "Maritime" region (which included all of Quebec!) suggested redpoll movements thither from farther west between November and January. Data from within the Maritimes (as discussed herein) are unsuitable for examining that possibility. The absence of any redpoll band returns between the Atlantic provinces and more western areas may reflect only the scarcity of passerine banders in the Maritimes. Redpolls that breed in Labrador might move to the southwest, bypassing the Maritimes - as do some Labrador-breeding birds that are scarce here except in western New Brunswick, e.g., White-crowned Sparrow (Zonotrichia leucophrys; AJE data). However, redpolls appear here in numbers frequently, and it seems more plausible that Labrador birds move here directly.

A few CBC "outliers" suggested that redpolls from Labrador sometimes might move to New Brunswick via insular Newfoundland and eastern Nova Scotia. The huge count at St. Anthony in December 1976 was in a winter when only one other CBC in the region (also in INF) found $>100$ redpolls. Most other large counts ( $>400$ unadjusted) in eastern Nova Scotia and Newfoundland occurred in 1968-69, winter of the most widespread regional invasion. Exceptionally high counts probably represented wandering flocks rather than movements within an invasion. The generally low redpoll numbers found in Newfoundland, and the species' frequent absences across much of Nova Scotia, argue against regular movement from Labrador to New Brunswick by way of Newfoundland.

Redpolls moving southward from Labrador and eastern Ungava probably cross the Gulf of St. Lawrence directly, as do many other migrating birds (also based on circumstantial evidence). Birds engaging in long overwater flights may be displaced by strong winds, which are frequent in the Gulf region. The strongest sustained winds in December 1991 at Moncton, New Brunswick (24-hr mean $28 \mathrm{~km} / \mathrm{hr}$, gusts to $45 \mathrm{~km} / \mathrm{hr}$, from west) occurred on the day preceding the huge flight of redpolls on Cape Tormentine CBC that year; that count seemingly detected the return westward of a major redpoll movement that had been displaced eastward by those winds. The few very high counts in southern sub-regions of the Maritimes, where redpolls are less frequent, may include "overflights", carried by strong tail-winds beyond usual destinations in southern New Brunswick.

We suggest that irregular abundance but nearannual occurrence of redpoll visitation, in the Atlantic Provinces, explains observed observations better than attempts to find periodicity in their irruptions.

\section{Acknowledgments}

We thank the many observers who contributed to regional CBCs over many years. John Chardine read and commented helpfully on an advanced draft of this article. Julie Sircom and Stefen Gerriets prepared the figures. The MS was prepared while AJE worked under an Emeritus appointment by Canadian Wildlife Service, Atlantic Region, Environment Canada, which provided computer, library, and office facilities. Stuart Houston and an anonymous reviewer provided helpful reviews of the submitted MS. 


\section{Literature Cited}

Bock, C. E., and L. W. Lepthien. 1976. Synchronous eruptions of boreal seed-eating birds. American Naturalist 110: 559-571.

Brewer, D., A. Diamond, E. J. Woodsworth, B. T. Collins, and E. H. Dunn. 2000. Canadian atlas of bird banding. Volume 1: Doves, cuckoos, and hummingbirds through passerines, 1921-1995. Special Publication/Canadian Wildlife Service, Environment Canada. 394 pages.

Bryson, R. 1966. Air masses, streamlines, and the boreal forest. Geographic Bulletin 8(3): 228-269.

Cadman, M. D., P. F. J. Eagles, and F. M. Helleiner. 1987. Atlas of the breeding birds of Ontario. Federation of Ontario Naturalists and Long Point Bird Observatory, University of Waterloo Press, Ontario. 617 pages.

Cyr, A., et J. Larivée. 1995. Atlas saisonnier des oiseaux du Québec. Presses de l'Université de Sherbrooke et Société de loisir ornithologique de l'Estrie, Sherbrooke, Québec. 711 pages.

Erskine, D. S. 1968. The Atlantic region. Chapter 9, pages 231-280 in Canada: A geographic interpretation. Edited by J. Warkentin. Toronto, Methuen.

Gauthier, J., and Y. Aubry. Editors. 1996. The breeding birds of Québec. Atlas of the breeding birds of southern Québec. Association québécoise des groupes ornithologiques, Province of Quebec Society for the Protection of Birds, Canadian Wildlife Service - Quebec Region. 1302 pages.
Godfrey, W. E. 1986. The birds of Canada. Revised edition. National Museum of Natural Sciences, Ottawa. 595 pages.

Hochachka, W. M., J. V. Wells, K. V. Rosenberg, D. L. Tessaglia-Hymes, and A. A. Dhondt. 1999. Irruptive migration of Common Redpolls. Condor 101: 195-204.

Houston, C. S., M. I. Houston, and A. R. Smith. 2000. Biennial redpoll invasions. Blue Jay 58: 116-124.

Keith, L. B. 1963. Wildlife's ten-year cycle. University of Wisconsin Press, Madison. 201 pages.

Kennard, J. H. 1976. A biennial rhythm in the winter distribution of the Common Redpoll. Bird-Banding 47: 231-237.

Larson, D. L., and C. E. Bock. 1986. Eruptions of some North American boreal seed-eating birds. Ibis 128: 137-140.

Loucks, O. L. 1962. A forest classification for the Maritime Provinces. Proceedings of the Nova Scotia Institute of Science 25: 85-167.

Newton, I. 1972. Finches. New Naturalist series. Collins, London. 288 pages.

Smith, A. R. 1996. Atlas of Saskatchewan birds. Saskatchewan Natural History Society, Special Publication number 22. 456 pages.

Todd, W. E. C. 1963. Birds of the Labrador peninsula. Carnegie Museum, Pittsburgh, Pennsylvania and University Toronto Press, Ontario. 819 pages.

Troy, D. M. 1983. Recaptures of redpolls: movements of an irruptive species. Journal of Field Ornithology 54: 146-151.

Received 23 October 2002

Accepted 20 November 2003

Appendix 1. Christmas Bird Counts (CBCs, latitude-longitude of centre given) used in redpoll study in Atlantic Provinces, grouped by sub-regions (defined in text, also see Figure 1).

Northern New Brunswick (N-NB)

Kouchibouguac National Park

Miramichi

Mount Carleton

Nictau

Perth-Andover

Plaster Rock

\section{Southern interior New Brunswick (S-NB)}

Cambridge-Narrows

Fredericton

Florenceville

Fundy National Park

Hampton

Hartland

Jemseg

Moncton

Riverside-Albert

Woodstock

$46^{\circ} 49^{\prime} \mathrm{N}, 64^{\circ} 55^{\prime} \mathrm{W}$

$47^{\circ} 00^{\prime} \mathrm{N}, 65^{\circ} 34^{\prime} \mathrm{W}$

$47^{\circ} 23^{\prime} \mathrm{N}, 66^{\circ} 53^{\prime} \mathrm{W}$

$47^{\circ} 14^{\prime} \mathrm{N}, 67^{\circ} 09^{\prime} \mathrm{W}$

$46^{\circ} 45^{\prime} \mathrm{N}, 67^{\circ} 42^{\prime} \mathrm{W}$

$46^{\circ} 54^{\prime} \mathrm{N}, 67^{\circ} 24^{\prime} \mathrm{W}$

$45^{\circ} 50{ }^{\prime} \mathrm{N}, 65^{\circ} 57^{\prime} \mathrm{W}$

$45^{\circ} 55^{\prime} \mathrm{N}, 66^{\circ} 35^{\prime} \mathrm{W}$

$46^{\circ} 27^{\prime} \mathrm{N}, 67^{\circ} 38^{\prime} \mathrm{W}$

$45^{\circ} 36^{\prime} \mathrm{N}, 65^{\circ} 01^{\prime} \mathrm{W}$

$45^{\circ} 32^{\prime} \mathrm{N}, 65^{\circ} 51^{\prime} \mathrm{W}$

$46^{\circ} 18^{\prime} \mathrm{N}, 67^{\circ} 32^{\prime} \mathrm{W}$

$45^{\circ} 52^{\prime} \mathrm{N}, 66^{\circ} 10^{\prime} \mathrm{W}$

$46^{\circ} 05^{\prime} \mathrm{N}, 64^{\circ} 37^{\prime} \mathrm{W}$

$45^{\circ} 45^{\prime} \mathrm{N}, 64^{\circ} 44^{\prime} \mathrm{W}$

$46^{\circ} 09^{\prime} \mathrm{N}, 67^{\circ} 35^{\prime} \mathrm{W}$

South coastal New Brunswick (ScoNB)

Eastport-Campobello

Grand Manan Island

Lepreau

Saint John

St. Andrews

N.B.-N.S. border area (Bord)

Amherst, N.S.

Cape Tormentine, N.B.

Sackville, N.B.
North and east Nova Scotia and Prince Edward Island (N-NS/PE)

Hillsborough, P.E.I.

Montague, P.E.I.

Prince Edward Island National Park

Cape Breton Highlands

National Park, N.S.

Glace Bay, N.S.

Springville, N.S.

\section{Southern Nova Scotia (S-NS)}

Brier Island

Broad Cove

Halifax (east) *

Halifax (west) *

Halifax-Dartmouth

Kingston

Shubenacadie

Wolfville

$46^{\circ} 08^{\prime} \mathrm{N}, 63^{\circ} 02^{\prime} \mathrm{W}$

$46^{\circ} 05^{\prime} \mathrm{N}, 62^{\circ} 35^{\prime} \mathrm{W}$

$46^{\circ} 23^{\prime} \mathrm{N}, 63^{\circ} 08^{\prime} \mathrm{W}$

$46^{\circ} 43^{\prime} \mathrm{N}, 60^{\circ} 23^{\prime} \mathrm{W}$

$46^{\circ} 13^{\prime} \mathrm{N}, 59^{\circ} 57^{\prime} \mathrm{W}$

$45^{\circ} 27^{\prime} \mathrm{N}, 62^{\circ} 38^{\prime} \mathrm{W}$

$44^{\circ} 16^{\prime} \mathrm{N}, 66^{\circ} 29^{\prime} \mathrm{W}$ $44^{\circ} 14^{\prime} \mathrm{N}, 64^{\circ} 27^{\prime} \mathrm{W}$ $44^{\circ} 41^{\prime} \mathrm{N}, 63^{\circ} 23^{\prime} \mathrm{W}$ $44^{\circ} 34^{\prime} \mathrm{N}, 63^{\circ} 38^{\prime} \mathrm{W}$ $44^{\circ} 36^{\prime} \mathrm{N}, 63^{\circ} 29^{\prime} \mathrm{W}$ $44^{\circ} 59^{\prime} \mathrm{N}, 64^{\circ} 57^{\prime} \mathrm{W}$ $45^{\circ} 05^{\prime} \mathrm{N}, 63^{\circ} 24^{\prime} \mathrm{W}$ $45^{\circ} 03^{\prime} \mathrm{N}, 64^{\circ} 23^{\prime} \mathrm{W}$

\section{Insular Newfoundland (INF)}

Bonne Bay

Corner Brook

Cape Race

Cape St. Mary's

St. Anthony

St. John's

Terra Nova National Park (north) $49^{\circ} 31^{\prime} \mathrm{N}, 57^{\circ} 53^{\prime} \mathrm{W}$ $48^{\circ} 57^{\prime} \mathrm{N}, 57^{\circ} 50^{\prime} \mathrm{W}$ $46^{\circ} 44^{\prime} \mathrm{N}, 53^{\circ} 09^{\prime} \mathrm{W}$ $46^{\circ} 52^{\prime} \mathrm{N}, 54^{\circ} 05^{\prime} \mathrm{W}$ $51^{\circ} 24^{\prime} \mathrm{N}, 55^{\circ} 35^{\prime} \mathrm{W}$ $47^{\circ} 33^{\prime} \mathrm{N}, 52^{\circ} 42^{\prime} \mathrm{W}$ $48^{\circ} 38^{\prime} \mathrm{N}, 53^{\circ} 54^{\prime} \mathrm{W}$ 


\section{Appendix 2. Redpoll data from Memramcook (McManus) and Sackville (Erskine), New Brunswick, by winter.}

Irruptions expected in OE winters). Only last two digits of years shown (1928-2002). For each winter are given: monthnumber(s) when redpolls noted (12=December, $1=$ January, etc.), total dates with redpolls, maximum/day (with month-number of maximum - omitted when only seen in one month). (Note: "none in notes" means none identified; "no notes" means expectable period of "flight" was missed).

\begin{tabular}{|c|c|c|c|}
\hline & \multicolumn{2}{|c|}{ [Even-Odd (EO) winters] } \\
\hline \multicolumn{2}{|c|}{$\underline{\text { Odd-Even }(\mathrm{OE}) \text { winters }}$} & [28-29] & $1,1 \mathrm{~d}, \mathrm{mx} 1+$ \\
\hline $29-30$ & none in notes & {$[30-31$} & none in notes] \\
\hline $31-32$ & $3,1 \mathrm{~d}, \mathrm{mx} 1$ & [32-33] & $11,3 \mathrm{~d}, \mathrm{~m} \times 25$ \\
\hline $33-34$ & no notes Nov-Mar & {$[34-35$} & none in notes] \\
\hline $35-36$ & $11,2 \mathrm{~d}, \mathrm{mx} 5+$ & {$[36-37$} & no notes all winter] \\
\hline $37-38$ & $12,1 \mathrm{~d}, \mathrm{mx} 11$ & {$[38-39$} & only 1 note Nov-Feb, none] \\
\hline $39-40$ & no notes all winter & {$[40-41]$} & $12-3,16 \mathrm{~d}, \mathrm{~m} \times 15(2)$ \\
\hline $41-42$ & $12,3,7 \mathrm{~d}, \mathrm{mx} 50(3)$ & {$[42-43$} & no notes all winter] \\
\hline $43-44$ & $11,12,5,25 \mathrm{~d}, \mathrm{mx} 50(11)$ & {$[44-45]$} & $2,2 \mathrm{~d}, \mathrm{~m} \times 2$ \\
\hline $45-46$ & notes only 28 Mar, none & {$[46-47]$} & $12-4,68 \mathrm{~d}, \mathrm{~m} \times 200(3)$ \\
\hline $47-48$ & $10,2-4,12 d, m \times 25(2)$ & [48-49] & $10-4,64 d, m \times 100+(3,4)$ \\
\hline $49-50$ & $10-4,29 \mathrm{~d}, \mathrm{mx} 100(3)$ & {$[50-51]$} & $1,2 \mathrm{~d}, \mathrm{mx} 1$ \\
\hline $51-52$ & notes only $14-16$ Nov, none & [52-53] & $11-4,111 d, \operatorname{mx} 150(3)$ \\
\hline $53-54$ & notes only $7 \mathrm{~d}$, none & [54-55] & $3,3 \mathrm{~d}, \mathrm{~m} \times 25$ \\
\hline $55-56$ & notes only $2 \mathrm{~d}$, none & [56-57] & $2,1 \mathrm{~d} . \mathrm{mx} 1$ \\
\hline $57-58$ & $11-2,4,37 \mathrm{~d}, \mathrm{mx} 750(1)$ & {$[58-59$} & no notes all winter] \\
\hline $59-60$ & $12-5,28 \mathrm{~d}, \mathrm{~m} \times 300+(12)$ & {$[60-61$} & no notes all winter] \\
\hline$\underline{59-60}$ & $\underline{4,1 \mathrm{~d}, \mathrm{mx} 40}$ & {$[\underline{60-61}$} & none seen or hd] \\
\hline $61-62$ & $10-4,15 \mathrm{~d}, \mathrm{~m} \times 20(11)$ & {$[62-63$} & none in notes] \\
\hline$\underline{61-62}$ & $\underline{12-2,6 \mathrm{~d}, \mathrm{mx} 23(12)}$ & [62-63] & $\underline{3,1 \mathrm{~d}, \mathrm{mx} 10}$ \\
\hline $63-64$ & $12,2-3,4 \mathrm{~d}, \mathrm{mx300(3)}$ & [64-65] & $11-2,6 \mathrm{~d}, \mathrm{~m} \times 2(11)$ \\
\hline$\underline{63-64}$ & $\underline{12,1 \mathrm{~d}, \mathrm{mx} 3}$ & [64-65] & $\underline{12-1,5 \mathrm{~d}, \mathrm{mx} 42(12)}$ \\
\hline$\overline{65-66}$ & $\overline{11,2-4,12 \mathrm{~d}}, \mathrm{mx} 84(12)$ & [66-67] & $\overline{12,1,3,4 \mathrm{~d}, \mathrm{mx} 10(12)}$ \\
\hline $65-66$ & $10,12,3-4,6 \mathrm{~d}, \mathrm{mx} 18(3)$ & {$[66-67]$} & $12,3.2 \mathrm{~d}, \mathrm{mx} 8(12)$ \\
\hline $67-68$ & none in notes & [68-69] & $10-4,85 \mathrm{~d}, \mathrm{mx} 120+(12)$ \\
\hline$\underline{67-68}$ & none seen or hd & {$[68-69$} & $11-12,6 \mathrm{~d}, \mathrm{mx} 25(12)$ \\
\hline$\overline{69-70}$ & 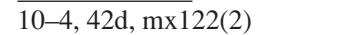 & {$[\overline{70-71}$} & $\overline{\text { none in notes] }}$ \\
\hline $71-72$ & $9-4,40 \mathrm{~d}, \mathrm{mx} 100 \mathrm{~s}(1)$ & {$[72-73]$} & $10,2,2 \mathrm{~d}, \mathrm{mx} 13(10)$ \\
\hline $73-74$ & $2,3,2 \mathrm{~d}, \mathrm{mx} 30(3)$ & {$[74-75$} & none in notes] \\
\hline $75-76$ & notes only $1-29$ Mar, none & {$[76-77$} & no notes all winter] \\
\hline $77-78$ & no notes all winter & {$[78-79$} & no notes all winter] \\
\hline$\underline{77-78}$ & $\underline{12-1,3,3 \mathrm{~d}, \operatorname{mx} 17(1)}$ & {$[78-79$} & none seen or hd] \\
\hline$\overline{79-80}$ & no notes all winter & {$[80-81]$} & $11,1 \mathrm{~d}, \mathrm{mx} 6$ \\
\hline 79-80 & none seen or hd & {$[\underline{80-81]}$} & 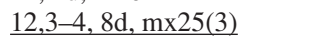 \\
\hline $81-82$ & $\overline{12,1 \mathrm{~d}, \mathrm{mx} 64}$ & {$[82-83$} & no notes all winter] \\
\hline$\underline{81-82}$ & $\underline{12-1,3-4,8 \mathrm{~d}, \mathrm{~m} \times 35+(4)}$ & {$[\underline{82-83}$} & none seen or hd] \\
\hline $83-84$ & $12-1,3,4 \mathrm{~d}, \mathrm{mx} 83(12)$ & [84-85 & none seen or hdl \\
\hline $85-86$ & $3,1 \mathrm{~d}, \mathrm{mx} 1$ & {$[86-87$} & no notes all winter] \\
\hline$\underline{85-86}$ & $\underline{11-12,2-3,6 \mathrm{~d}, \mathrm{mx} 10(11)}$ & {$[\underline{86-87]}$} & $\underline{12-2,10 \mathrm{~d}, \mathrm{mx} 51(2)}$ \\
\hline $87-88$ & $11-2,8 \mathrm{~d}, \mathrm{mx} 31(12)$ & {$[88-89$} & none seen or hd] \\
\hline$\overline{89-90}$ & $\underline{1,1 \mathrm{~d}, \mathrm{mx} 15}$ & [90-91] & $4,1 \mathrm{~d}, \mathrm{mx} 2$ \\
\hline $91-92$ & $11-2,11 \mathrm{~d}, \mathrm{~m} \times 325+(12)$ & [92-93 & none seen or hdl \\
\hline $93-94$ & $11,1,6 \mathrm{~d}, \mathrm{mx} 40$ & [94-95 & no notes all winter] \\
\hline 93-94 & $\underline{11-4,35 \mathrm{~d}, \mathrm{mx} 40+(3)}$ & [94-95 & none seen or hd] \\
\hline $95-96$ & $12-3,9 \mathrm{~d}, \operatorname{mx} 10(1)$ & [96-97 & none seen or hd] \\
\hline$\underline{97-98}$ & $\underline{11-3,20 \mathrm{~d}, \mathrm{mx} 40+(12,3)}$ & [98-99] & $\underline{11,1 \mathrm{~d}, \mathrm{mx} 5}$ \\
\hline $99-00$ & $11-3,38 \mathrm{~d}, \mathrm{mx} 58+(12)$ & {$[00-01$} & none seen or hdl \\
\hline$\underline{01-02}$ & $11-4,72 \mathrm{~d}, \mathrm{mx} 86+(1)$ & & \\
\hline
\end{tabular}




\section{Appendix 3. Summary of Atlantic Provinces Redpoll CBC data}

For each winter (dated by start year, 2 digits), data are grouped geographically: N-NB, S-NB, ScoNB; Bord; N-NS/PE, S-NS; INF (see text for area definitions, also Figure 1); for each five-year series, maximum numbers of circles counted in any one year in each group are shown; within each group and year, numbers shown are: number of counts with 0 redpolls; number of counts with $>=50$ birds; highest count (latter two figures adjusted to birds/10 party-hours). (n.d.) = data missing.

\begin{tabular}{|c|c|c|c|c|c|c|c|c|}
\hline Yr & \multicolumn{2}{|c|}{$\mathrm{N}-\mathrm{NB}$} & S-NB & ScoNB & Bord & $\mathrm{N}-\mathrm{NS} / \mathrm{PE}$ & S-NS & INF \\
\hline \multicolumn{9}{|c|}{ Maximum number of CBCs used in each region 1960-1964 } \\
\hline & \multicolumn{2}{|l|}{0} & 5 & 3 & 3 & 2 & 4 & 0 \\
\hline 60 & & & $2,0,2$ & $3,0,0$ & $1,0,0$ & $1,0,0$ & $2,0,15$ & \\
\hline 61 & & & $1,2,107$ & $1,1,25$ & $1,1,92$ & $1,0,0$ & $3,0,0$ & \\
\hline 62 & & & $3,0,9$ & $2,0,0$ & 2,0 & $11,0.0$ & $4.0,0$ & \\
\hline 63 & & & $2,0,6$ & $3,0,2$ & $2,0,3$ & (n.d.) & $2,0,0$ & \\
\hline \multirow[t]{3}{*}{64} & & & $1,0,35$ & $3,0,0$ & $0,0,28$ & $2,0,0$ & $3,1,200$ & \\
\hline & \multicolumn{8}{|c|}{ Maximum number of CBCs used in each region $1965-1969$} \\
\hline & 2 & & 6 & 4 & 3 & 3 & 5 & 2 \\
\hline 65 & & & $1,3,131$ & $3,0,10$ & $0,2,77$ & $1,0,4$ & $1,0,9$ & \\
\hline 66 & & & $3,0,5$ & $2,0,4$ & $2,0,5$ & $2,0,0$ & $3,0,<1$ & $1,0,0$ \\
\hline 67 & & & $3,0,1$ & $2,0,4$ & $3,0,0$ & $3,0,0$ & $2,0,14$ & $1,0,0$ \\
\hline 68 & & & $0,5,695$ & $0,3,106$ & $0,2,107$ & $0,1,278$ & $0,5,270$ & $0,2,163$ \\
\hline \multirow[t]{3}{*}{69} & 0,0 & 27 & $0,3,173$ & $0,2,667$ & $0,2,88$ & $1,0,11$ & $2,1,83$ & $1,0,8$ \\
\hline & \multicolumn{8}{|c|}{ Maximum number of CBCs used in each region $1970-1974$} \\
\hline & \multicolumn{2}{|c|}{5} & 9 & 5 & 3 & 5 & 7 & 4 \\
\hline 70 & 1,0 & 0 & $5,0,3$ & $4,0,<1$ & $2,0,<1$ & $2,0,<1$ & $2,0,2$ & $2,0,0$ \\
\hline 71 & 1,0 & 10 & $0,4,210$ & $0,1,125$ & $0,1,52$ & $0,2,59$ & $3,0,28$ & $2,0,<1$ \\
\hline 72 & 3,0 & 10 & $3,0,19$ & $4,0,8$ & $1,0,8$ & $4,0,19$ & $2,0,15$ & $2,0,1$ \\
\hline 73 & 2,1 & 85 & $3,3,77$ & $3,0,4$ & $2,0,26$ & $3,0,15$ & $6,0,8$ & $2,1,130$ \\
\hline \multirow[t]{3}{*}{74} & 4,1 & 53 & $4,0,22$ & $4,0,0$ & $3,0,0$ & $4,0,0$ & $5,0,2$ & $2,1,91$ \\
\hline & \multicolumn{8}{|c|}{ Maximum number of CBCs fused in each region 1975-1979 } \\
\hline & \multicolumn{2}{|c|}{6} & 9 & 5 & 3 & 5 & 7 & 6 \\
\hline 75 & 1,1 & 71 & $0,4,111$ & $1,0,19$ & $0,2,105$ & $1,0,14$ & $3,1,80$ & $2,0,<1$ \\
\hline 76 & 1,0 & 40 & $2,0,33$ & $0,0,12$ & $1,0,14$ & $4,0,2$ & $2,0,6$ & $2,2,1110$ \\
\hline 77 & 1,1 & 75 & $1,4,289$ & $1,3,167$ & $0,0,49$ & $4,0,26$ & $3,0,38$ & $2,0,23$ \\
\hline 78 & 0,4 & 109 & $1,1,129$ & $2,0,3$ & $2,0,16$ & $5,0,0$ & $5,0,17$ & $3,1,50$ \\
\hline \multirow[t]{3}{*}{79} & 3,0 & 26 & $4,0,7$ & $2,0,27$ & $2,0,6$ & $5,0,0$ & $7,0,0$ & $3,0,8$ \\
\hline & \multicolumn{8}{|c|}{ Maximum number of CBCs used in each region 1980-1984 } \\
\hline & \multicolumn{2}{|c|}{6} & 9 & 5 & 3 & 6 & 7 & 7 \\
\hline 80 & 1,1 & 250 & $0,4,117$ & $0,1,72$ & $0,0,44$ & $3,0,39$ & $1,2,74$ & $4,0,13$ \\
\hline 81 & 2,2 & 217 & $0,7,456$ & $1,2,70$ & $0,2,186$ & $2,2,84$ & $1,3,163$ & $0,0,35$ \\
\hline 82 & 3,0 & 8 & $4,0,20$ & $5,0,0$ & $2,0,2$ & $6,0,0$ & $3,1,98$ & $3,0,8$ \\
\hline 83 & 2,1 & 75 & $3,0,20$ & $1,1,55$ & $1,1,98$ & $4,0,12$ & $4,0,21$ & $1,0,36$ \\
\hline 84 & 5,0 & 2 & $5,0,12$ & $4,0,0$ & $1,0,11$ & $6,0,0$ & $6,0,1$ & $4,0,20$ \\
\hline & & & Maximum & er of $\mathrm{CB}$ & ed in eacl & ion $1985-$ & & \\
\hline & & & 10 & 5 & 3 & 6 & 7 & 6 \\
\hline 85 & 1,1 & 125 & $0,4,262$ & $1,0,11$ & $0,2,97$ & $2,1,170$ & $1,0,30$ & $0,2,96$ \\
\hline 86 & 0,5 & 274 & $0,5,501$ & $0,0,33$ & $0,2,90$ & $1,1,171$ & $1,4,163$ & $1,0,11$ \\
\hline 87 & 1,3 & 109 & $1,4,808$ & $3,0,10$ & $0,2,100$ & $5,0,0$ & $6,0,<1$ & $1,0,17$ \\
\hline 88 & 2,0 & 23 & $4,0,31$ & $4,0,<1$ & $1,0,10$ & $4,0,4$ & $7,0,0$ & $3,0,<1$ \\
\hline 89 & 4,1 & 57 & $1,3,122$ & $4,0,17$ & $1,0,35$ & $2,0,36$ & $2,1,105$ & $4,0,<1$ \\
\hline & & & Maximum & er of $\mathrm{CB}$ & ed in eacl & ion 1990 & & \\
\hline & & & 10 & 5 & 3 & 6 & 6 & 6 \\
\hline 90 & 2,1 & 308 & $4,0,16$ & $5,0,0$ & $3,0,0$ & 6,00 & $5,0,<1$ & $5,0,1$ \\
\hline 91 & 1,3 & 311 & $0,5,301$ & $0,0,24$ & $0,3,3540$ & $2,2,394$ & $3,1,50$ & $0,0,17$ \\
\hline 92 & 4,0 & 43 & $7,0,15$ & $4,0,15$ & $3,0,0$ & $6,0,0$ & $5,0,<1$ & $4,1,53$ \\
\hline 93 & 1,1 & 70 & $0,5,693$ & $0,0,22$ & $0,2,55$ & $0,3,120$ & $0,1,380$ & $1,1,43$ \\
\hline 94 & 4,0 & 7 & $3,1,65$ & $3,0,<1$ & $2,0,3$ & $3,0,14$ & $4,0,3$ & $5,0,2$ \\
\hline & & & Maximum & er of $\mathrm{CB}$ & ed in eacl & ion $1995-$ & & \\
\hline & & & 10 & 5 & 3 & 5 & 6 & 6 \\
\hline 95 & 0,2 & 174 & $0,7,204$ & $2,0,41$ & $0,0,25$ & $1,2,108$ & $1,1,75$ & $1,0,8$ \\
\hline 96 & 3,1 & 53 & $6,0,18$ & $5,0,0$ & $3,0,0$ & $3,1,73$ & $5,0,1$ & $4,0,28$ \\
\hline 97 & 0,3 & 125 & $0,6,313$ & $2,0,10$ & $0,1,67$ & $0,4,431$ & $0,4,278$ & $0,0,9$ \\
\hline 98 & 4,0 & 34 & $3,0,22$ & $4,0,30$ & $3,0,0$ & $5,0,0$ & $6,0,0$ & $4,1,82$ \\
\hline 99 & 1,2 & 136 & $0,8,422$ & $0,1,172$ & $0,3,158$ & $0,4,699$ & $1,2,1253$ & $0,0,43$ \\
\hline & & & Maximum & er of $\mathrm{CB}$ & ed in eacl & ion 2000 & & \\
\hline & & & 9 & 5 & 3 & 6 & 6 & 0 \\
\hline 00 & 3,0 & 18 & $6,0,28$ & $4,1,80$ & $1,0,8$ & $3,0,3$ & $6,0,0$ & n.d. \\
\hline 01 & 0,4 & 107 & $0,5,104$ & $1,0,12$ & $0,1,105$ & $0,2,95$ & $0,4,330$ & n.d. \\
\hline
\end{tabular}

